Г. В. Пристай, Б. Р. Пристай

\title{
МОРФОНОЛОГІЧНІ ТРАНСФОРМАЦІЇ У СЛОВОТВІРНИХ ГНІЗДАХ ПРИКМЕТНИКІВ 3 ВЕРШИНАМИ НА -Р(ИЙ)
}

Пристай Г. В., Пристай Б. Р. Морфонологічні трансформації у словотвірних гніздах прикметників з вершинами на -р(ий).

У статті проаналізовано словотвірні гнізда прикметників на -p(ий) 3 погляду морфонології: здійснено формально-граматичну характеристику вершинних слів, описано морфемну будову мотивувальних основ $\mathrm{i}$ дериваційних суфіксів, проаналізовано структуру контактних зон, схарактеризовано морфонологічні позиції та описано базові морфонологічні модифікації, які маркують відприкметникові деривати.

Ключові слова: морфонологічні трансформації, словотвірне гніздо, чергування.

Пристай Г. В., Пристай Б. Р. Морфонологические трансформации в словообразовательных гнездах прилагательных с вершинами на -р(ый)

В статье проанализированы словообразовательные гнезда прилагательных на -р(ый) с точки зрения морфонологии: осуществлена формально-грамматическая характеристика вершинных слов, описана морфемная структура мотивировочных -193- ОГ. В. Пристай, Б. Р. Пристай, 2015. 
основ и деривационных суффиксов, проанализирована структура контактных зон, охарактеризованы морфонологические позиции и описаны базовые морфонологические модификации, которые маркируют деадъективы.

Ключевые слова: морфонологические трансформации, словообразовательное гнездо, чередование.

Prystai H. V., Prystai B. R. Morphonological transformations of derivational nests with the top adjectives ending $-\mathrm{r}(\mathrm{yi})$.

The article deals with the analysis of the adjectival derivatives of the point of view of morphonology. A central issue is in formal grammatical description of top adjectives. This paper focused on the morpheme structure of the motivation stems and the derivational suffixes. The data indicate the structure the contact zone, morphonological positions and the main modifications within the analysed word building nests.

Key words: morphonological transformations, word building nest, alternation.

Одне із провідних завдань сучасної україністики - усебічне вивчення різноманітних процесів, які відбуваються на морфемному шві. Теоретичні підвалини таких студій закладено в монографічних дослідженнях В. Лопатіна, Н. Клименко, В. Грещука, С. Карпіловської, Л. Гумецької, В. Горпинича, М. Кравченко та ін. Динамічний підхід до розгляду супутніх словотворенню морфонологічних явищ дає змогу встановити причини, які стимулюють зміни формального вияву морфем, 3’ясувати їхню (змін) функціональну значущість.

Українській мові, як і багатьом мовам світу, властива зміна фонемного складу морфем при їх з'єднанні. Закономірності й особливості формальних модифікацій у морфемній структурі слова на матеріалі слов'янських і германських мов досліджено у працях Е. Станкевича, Г. Аронсона, . Дресслера, Я. Босака, Р. Лясковського, К. Ковалик, В. Касевича, Г. Андерсена, О. Реформатського, С. Бернштейна, Ю. Маслова, О. Земської, В. Лопатіна, І. Улуханова, М. Панова, С. Толстої, Т. Попової, Е. Макаєва, О. Кубрякової, Ю. Панкраца та ін. Синхронний опис морфонологічних закономірностей відіменникового словотворення української мови уклала М. Федурко, функціональну навантаженість морфонологічних альтернацій іменникової словозміни з'ясувала Л. Комарова, дієслівної словозміни - І. Козленко, морфонологічну валентність віддієслівних похідних опрацьовано І. Демешко.

Мета пропонованої розвідки - описати й детально проаналізувати морфонологічні модифікації, релевантні для словотвірних гнізд прикметників із вершиною на -p(uй). Із поставленої мети випливають такі завдання: 1) з'ясувати морфонологічну структуру дериваційних морфем основ і суфіксів; 2) проаналізувати морфонологічно важливі ознаки (ㄷ Г. В. Пристай, Б. Р. Пристай, 2015. 


\section{СТРУКТУРА I СЕМАНТИКА МОВНИХ ОДИНИЦЬ}

прикметникових коренів та поєднуваних 3 ними афіксальних морфем; 3) вивчити умови виникнення й схарактеризувати морфонологічні позиції, властиві словотвірним гніздам прикметників на -p(uй); 4) описати морфонологічні зміни, що характеризують деад'єктиви усіх морфологічних блоків словотвірних парадигм усіх ступенів похідності.

Проаналізований морфонологічний тип представлений 26 словотвірними гніздами непохідних прикметників. Вершини обстежуваного типу різні за значенням та називають:

1) особливості характеру та психічного складу людини (бадьорий, добрий, мудрий, понурий, скнарий, скорий, суворий, хоробрий, щчирий, щедрий, шустрий); 2) фізичні та фізіологічні якості людини / тварини (хорий, хворий, старий); 3) ознаки предметів / істот щодо кольору, масті (мурий, карий, сірий, бурий, ярий); 4) властивості предметів за безпосереднім фізичним враженням чи за їхніми зовнішніми характеристиками (сирий, гострий, бистрий).

Морфонологічне дослідження відприкметникових словотвірних гнізд (далі - СГ) передбачає аналіз морфонологічної структури коренів / основ. Переконані, що корінь вершинного прикметника у СГ впливає на семантику, а в поєднанні з тими чи тими афіксами його значення уточнюється. Скажімо, корінь непохідного ад’єктива сір(ий) зі значенням 'колір, середній між білим і чорним; барва попелу' програмує й передає своє значення похідним. В іменнику сір-ин(a) 'cipa барва чого-небудь' значення кореня сір- уточнюється за допомогою суфікса на позначення узагальненої ознаки -ин-. Прикметник сір-ісіньк(uй) 'зовсім, дуже сірий' виражає суб'єктивну оцінку якості за допомогою суфікса -ісіньк-. Дієслово cip-i-mu 'ставати, робитися сірим, сірішим' увібрало компонент значення кореня та змінилося внаслідок поєднання з суфіксом на позначення дії $-i$ Отже, за походженням у цих словах корінь прикметниковий.

Морфонологічно значуща особливість - формальна нечленованість структури основ, яка «певною мірою програмує морфонологічні параметри дериватів» [4, с. 84]. Проаналізовані корені закінчуються одиничним консонантом $\{p\}$ (старий, сірий, хворий, мурий, сирий, бадьорий, понурий, суворий, щуирий, хорий, карий, бурий, скорий, шустрий, ярий) або містять у фіналі сполуку морфонем - шумної (шумних) вибухової й сонорної: $\{\partial p\}$ (мудрий, щедрий), \{бр\} (добрий, хоробрий), \{mp\} (хитрий), \{кр\} (прикрий), $\{c m p\}$ (гострий, бистрий, шустрий). У позиції вокалічної морфонеми вживаються сталі морфонеми $\{o\},\{y\},\{a\},\{u\},\{e\},\{i\}$. Тип кореня - одноабо двоскладовий. Г. Нещименко підкреслює, що для адекватного аналізу важливо враховувати «фонологічну маніфестацію фінального сегмента 
основи», т. зв. контактної зони, адже його форма безпосередньо впливає на вибір словотворчого афікса та на морфонологічну структуру похідного [3, с. 305]. Проаналізовані прикметникові корені взаємодіють в основному 3 вокалічними суфіксами.

Характерна ознака аналізованих гнізд - 4 зони похідності на I-ому ступені словотворення: прикметникова, іменникова, дієслівна, прислівникова.

Прикметникову зону формують прикметники 3 суфіксами на позначення: 1) суб'єктивної оцінки якості предмета: -езн-, -енн-, -еньк-, -есеньк-, -ісіньк- (сір(ий) $\rightarrow$ сір-еньк(ий), сір-есеньк(ий), сір-ісіньк(ий); щуир (ий) $\rightarrow$ щчир-еньк(ий), щчир-есеньк(ий), щуир-ісіньк(ий); сир(ий) $\rightarrow$ сир-

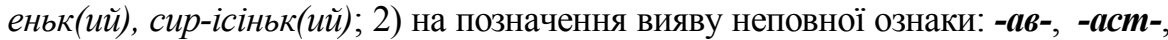
-ов/асm-, -ист-, -овит-, -yват-, -к/уват- (бур(ий) $\rightarrow$ бур-аст(ий), бур-ав(ий); мур (ий) $\rightarrow$ мур-ов/аст(ий), мур-ан/ист(ий); бадьор(ий) $\rightarrow$ бадьор-ист(ий), сір (ий) $\rightarrow$ сір-яв(ий); хор(ий) $\rightarrow$ хор-овит(ий), хор-уват(ий); стар(ий) $\rightarrow$ стар-к/уват(ий); 3) на позначення великої міри якості: -езн-, -енн- (стар (ий) $\rightarrow$ стар-езн(ий); добр(ий) $\rightarrow$ добр-енн(ий); 4) компаративи на -іш(ий) $($ гостр (ий) $\rightarrow$ гостр-ім(ий); скор (ий) $\rightarrow$ cкор-іш(ий); щир (ий) $\rightarrow$ щиир-іш(ий); cup $(u \check{u}) \rightarrow$ cup-iш(uй). Зауважмо, що компаративний суфікс-іш- розглядаємо серед словотворчих афіксів, адже форми, утворені за їхньою участю, функціонують як мотивувальні, базові для певних категорій похідних, тобто вони беруть безпосередню участь у розбудові словотвірних гнізд (гостр (uй) $\rightarrow$ гостр-іш(ий) $\rightarrow$ гостріш-а-ти $\rightarrow$ по-гострішати; ичир(ий) $\rightarrow$ щчир-іш(ий) $\rightarrow$ най-щиріший $\rightarrow$ як-найщиріший $\rightarrow$ якнайщчиріш-е.

Найбільшу кількість похідних зареєстровано в іменниковому блоці аналізованих гнізд. До їхнього творення залучено суфіксальні морфи на позначення: 1) назв осіб / предметів / речовин - суфікси -ець, -ів/ець $($ щзир (ий) $\rightarrow$ щир-ещьь; сирий $\rightarrow$ сир-ецьь, сир-ів/ещьь; -ак, -'ак (мудр(ий) $\rightarrow$ мудр-ак; сір(ий) $\rightarrow$ сір-як; гостр (ий) $\rightarrow$ гостр-як; добр(ий) $\rightarrow$ добр-як);-ій $($ стар $($ ий $\rightarrow$ cmap-ій; мудр(ий) $\rightarrow$ мудр-ій); -ик (стар (ий) $\rightarrow$ стар-ик; хитр (ий) $\rightarrow$ хитр-ик; гостр (ий) $\rightarrow$ гостр-ик); -иц'-, -ов/иц'- (стар (ий) $\rightarrow$ стар-иц(я) 'старе русло; жебрачка' [1, с. 1189]; щзир(ий) $\rightarrow$ щุир-иц(я); сир(ий) $\rightarrow$ сир-ов/ии(я); -к- (мур(ий) $\rightarrow$ мур-к(о); сір(ий) $\rightarrow$ сір-к(о); -ук $($ cтар $($ ий $) \rightarrow$ cтар-ук); -yx- (cmap (uй) $\rightarrow$ cmap-yx(a); гостр (uй) $\rightarrow$ гостр-

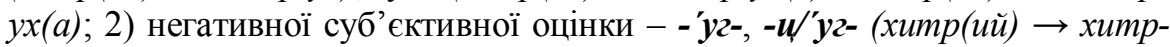
юг(a); скнар (ий) $\rightarrow$ скнар-юг(a); стар (ий) $\rightarrow$ cтар-и/юг(a); 3) узагальнених і абстрактних назв - -изн-, -ов/изн-, -ин-, -ов/ин-, -ість, -інь, -аціј- (сір (ий) $\rightarrow$ сір-изн(a), сір-ин(а), сір-ість; стар (ий) $\rightarrow$ стар-ов/изн(а), стар-ин(а), стар-ість; сир (ий) $\rightarrow$ щчир(ий) $\rightarrow$ щцир-ість; бистр $($ й) $\rightarrow$ бистр-ин $(a)$,

С Г. В. Пристай, Б. Р. Пристай, 2015. 
бистр-інь; яр(ий) $\rightarrow$ яр-ин(а); сир(ий) $\rightarrow$ сир-ов/ин(а), сир-ість; мудр(ий) $\rightarrow$ мудр-ість, мудр-аиіј(a) 'що-небудь складне, трудне'). В іменниковому блоці обстежуваних гнізд зафіксовано уніфікси -иган, -игань, -оман, -оманець, -агель (стар (ий) $\rightarrow$ стар-иган, стар-игань; сір(ий) $\rightarrow$ сір-оман, сір-оманець; мудр (ий) $\rightarrow$ мудр-агель).

Похідні дієслівного блоку І-ого ступеня утворено за допомогою дериваційних суфіксів -и-, -i-, -yва-, конфікса $\boldsymbol{y}$-...-u- (хитр(ий) $\rightarrow$ хитрu-mи, хитр-i-ти, хитр-ува-ти; мудр(ий) $\rightarrow$ мудр-i-mи, мудр-ува-ти, $y$ мудр-и-ти; стар (ий) $\rightarrow$ стар-и-ти, стар-i-ти, бур(ий) $\rightarrow$ бур-i-ти; хвор $($ ии) $\rightarrow$ хвор-і-ти; хор (ий) $\rightarrow$ хор-ува-ти).

Деад'єктивні прислівники залучають до словотвору суфікси -о

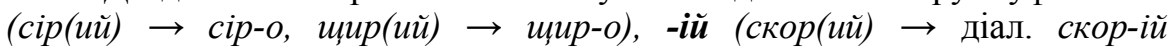
$[1$, с. 1140]), конфікси по-...-ому (добр (ий) $\rightarrow$ по-добр-ому; щир $($ ий) $\rightarrow$ nощиир-ому), з- (c-)...-a (-y) (мудр(ий) $\rightarrow$ з-мудр-а).

Середня глибина гнізд аналізованого типу - 2-3 дериваційні кроки. Проілюструємо на прикладі словотвірного гнізда «сірий»: cip(uй)

$$
\begin{aligned}
& \text { сір-еньк(ий) } \\
& \text { сір-есеньк(ий) } \\
& \text { сір-ісіньк(ий) } \\
& \text { сір-ім(ий) } \\
& \text { сір-уват(ий) } \\
& \text { сір-яв(ий) } \\
& \text { сір-ин(a) } \\
& \text { сір-ин(a) } \\
& \text { сір-ість } \\
& \text { сір-к(о) } \\
& \text { сір-ом(а) } \\
& \text { сір-як }
\end{aligned}
$$$$
\text { сір-есеньк(ий) }
$$$$
\text { сір-ісіньк(ий) }
$$$$
\text { сір-imu }
$$

cip-o $\rightarrow$ сіреньк-о

$\rightarrow$ сіресеньк-о

$\rightarrow$ cipiu-a-mu

$\rightarrow$ сіруват-ість сіруват-о

$\rightarrow$ сіряв-ість

$$
\begin{aligned}
& \begin{array}{c}
\rightarrow \text { сіряч-ок } \\
\text { сіряч-ин(a) } \\
\text { сір-ячк (a) }
\end{array} \\
& \rightarrow \text { no-cipimu } \\
& \text { сіріти-ся }
\end{aligned}
$$

$\rightarrow$ по-сірішати

Прикметник із значенням кольору карий 'чорний, темний' $[1$, c. 345], зафіксовано в лексикографічних джерелах як такий, що не спродукував жодного похідного. СГ 3 вершинами бурий 'темнокоричневий із сіруватим або червонуватим відтінком' [1, с. 67], мурий 'темно-сірий, сіро-бурий' $[1,545]$ мають у своєму складі тільки похідні 
прикметники, іменники або дієслова.

Установити пристосування й видозміну морфем у морфемній структурі слова при деривації допомагає поняття морфонологічної позиції. Фактичний матеріал дав змогу виокремити такі морфонологічні позиції у проаналізованих СГ: палаталізація приголосних фонем, нарощення суфікса, акцентні позиції.

Позиція палаталізації вимагає альтернації твердого кінцевого консонанта основи $/ p / 3$ його м'яким корелятом $/ p$ '. Морфонологічне чергування підготовляє основу до поєднання з словотворчим суфіксом. Неперехідну палаталізацію кінцевої фонеми зумовлюють ті суфікси, що містять в ініціалі $\{i\},\{a\},\{y\}$. До них належать: 1) прикметникові суфікси -іськ- (добр (ий) $\rightarrow$ добр'-іськ(ий); -ісіньк- (сир(ий) $\rightarrow$ сир' -ісіньк(ий); -іш$($ бистр (ий) $\rightarrow$ бистр'-ім(ий), -'ав- (сір(ий) $\rightarrow$ сір'-ав(ий); -'yч- (хитр(ий) $\rightarrow$ хитр'-уч(ий); -'ущ- (гостр (ий) $\rightarrow$ гостр'-ущ⿻(ий); 2) іменникові -ість $($ щир $($ ий) $\rightarrow$ щиир'-ість); -інь (бистр (ий) $\rightarrow$ бистр'-інь); -ій (мудр(ий) $\rightarrow$ мудр'-ій); -ав'- чорн (ий) $\rightarrow$ чорн'-ав(а); -'аг- (добр (ий) $\rightarrow$ добр'-аг(a); - 'ак $($ гостр (ий) $\rightarrow$ гостр'-ак); -'уг- (скнар (ий) $\rightarrow$ скнар'-уг(a); 3 ) дієслівні -і-

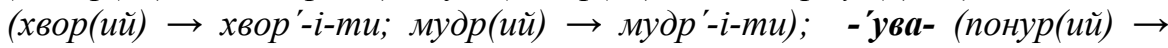
понур'-ува-ти; гостр (ий) $\rightarrow$ за-гостр'-ува-ти).

Нарощення дериваційних суфіксів (субморфемізація) за деад'єктивного словотворення зумовлена нетиповими для структури української мови сполуками фонем у контактній зоні. Основна функція субморфеми - сполучна [2, с. 26]. Окрім того, процес нарощення детермінує збільшення кількості формальних репрезентантів морфем. У морфонологічну позицію нарощення потрапляють прикметникові суфіксальні морфеми: -к/уват- (понур(ий) $\rightarrow$ понур-к/уват(ий); - $\mathbf{a н} / \mathbf{u c m - ~}$ $($ мур $($ ий) $\rightarrow$ мур-ан/ист(ий); іменникові: -ов/изн- $($ стар $($ ий) $\rightarrow$ cтар-

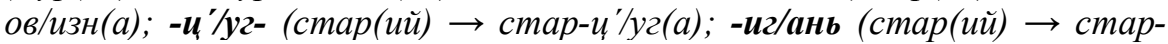

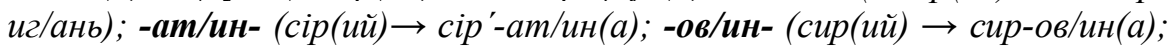
-ов/иц'- (сир (ий) $\rightarrow$ cup/oв/uи'(a); дієслівний суфікс -ц'/ува- (стар (ий) $\rightarrow$ стар-й'/ува-ти).

Наголос у процесах словотворення виконує конститутивну функцію, організовуючи навколо себе певну кількість словотвірно визначених морфів, об'єднуючи їх у слово [2, с. 200]. Морфонологічна позиція зміни місця наголосу детермінована морфемною структурою похідного, зокрема структурою та морфонологічними властивостями суфікса-дериватора. Як засвідчив обстежений матеріал, найбільш поширена акцентна позиція переміщення наголосу на суфікс: сі́p(uй) $\rightarrow$ cip-е́ньк(uй), сіре́ сеньк(uй), сір-ува́т(ий), сіромм(а), сірома́н; бу́ р(ий) $\rightarrow$ бур-а́в(ий), бур-а́ст(ий), С Г. В. Пристай, Б. Р. Пристай, 2015. 


\section{СТРУКТУРА I СЕМАНТИКА МОВНИХ ОДИНИЦЬ}

бур-ува́т(ий); сир(и́ü) $\rightarrow$ сир-ува́m(ий), сир-е́иь, сири́ú(a) 'недублена шкіра' [1, с. 1125], сир-ни́к, сирня к'сирі дрова' [1, с. 1125]; стар (úü) $\rightarrow$ стар-езз(ий), старенн(ий), стареннк(ий), стареч(ий), старуват(ий), стар-ига́н, старига́нь, стариззн(a), стар-ик, стариич'(a), стар-у́х(а), стар-и-ти, діал. стар-ува́-ти 'говорити як стара людина' [1, с. 1190];

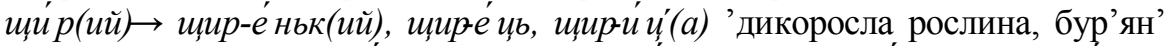
$[1$, c. 1414]; діал. хо́р(ий) $\rightarrow$ хор-ови́m(ий), хорува́m(ий), хоробб(a), хор-о́m(а), хорува́-ти; му др(ий) $\rightarrow$ мудр-ува́т(ий), мудр-аге́ль, мудра́к, мудр-а́ й̈(а), мудр-е́ иъ, мудрува́-ти; го стр (ий) $\rightarrow$ гостр-е́ ньк(ий), гостр ува́т(ий), гостре́иь, гострухх(а), гостри-ти; до́бр(ий) $\rightarrow$ добр-е́нн(ий), добр-е́ньк(ий), добре́сеньк(ий), добр-и́-ти; хйтр(ий) $\rightarrow$ хитр-е́ньк(ий), хитр-ин(а), хитри-ти. Крім того, зафіксовано альтернацію наголоса на

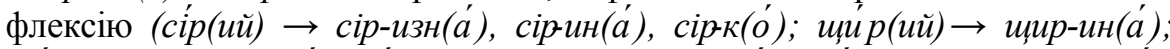
му' $($ ий $\rightarrow$ мур-к(ó); го́ стр (ий) $\rightarrow$ гостр-от(á); до́брй $\rightarrow$ добр-от(á),

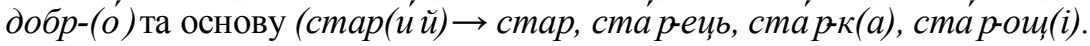

У деад'єктивному словотворчому акті можливе поєднання морфонологічних позицій: одна позиція створює умови для іншої. Наприклад, іменниковий суфікс на позначення абстрактних понять -icmь завжди перебуває у преакцентній морфонологічній позиції й зумовлює водночас чергування за твердістю / м'якістю та переміщення наголосу 3

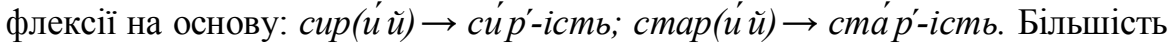
словотворчих суфіксальних морфем у позиції палаталізації перетягують

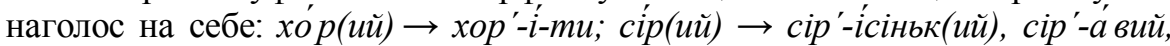

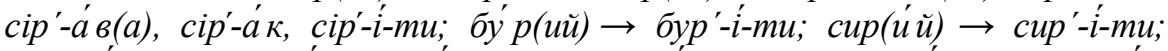

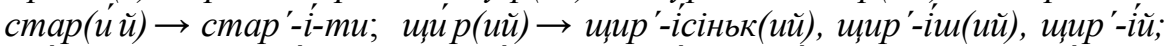

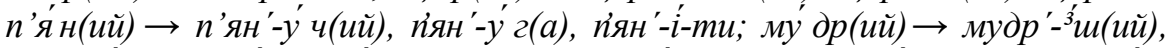

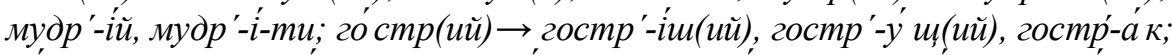

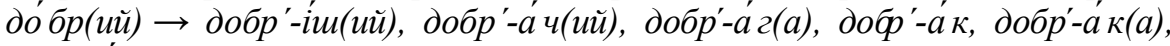
добр'-í-mи. Комбінацію морфонологічних трансформацій нарощення суфікса й чергування наголосу, (з флексії на суфікс) демонструють деад'єктиви на зразок стар (úŭ) $\rightarrow$ стар-к/ува́m(ий), старов/uззн(a),

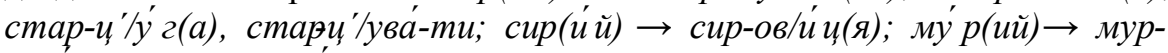
aн/u cm(uй), мур-ов/á cm(uй). Нарощений аутоакцентний суфікс «вимагає» пом'якшення основи в словотвірній парі (cíp(uй) $\rightarrow \operatorname{cip}^{\prime}-a^{\prime} m / u н(a)$; $\operatorname{cup}\left(u^{\prime} u \check{)}\right)$

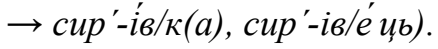

Основи похідних II-ого та III-ого ступенів, долучаючись до дериваційних процесів, можуть зазнавати пом'якшення фіналі основи

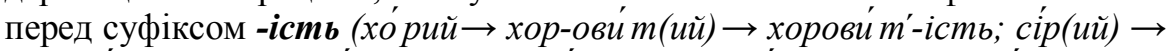

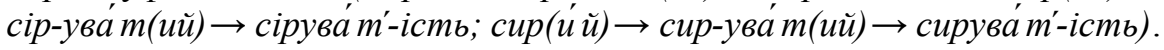

-199- ОГ.В.Пристай, Б. Р. Пристай, 2015. 
Акцент зміщується на суфікс перед одиницями -ax-, -am, -ux-

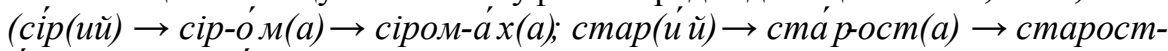
ám, cmapocm-ux (a). Аутокцентний префікс ви- детермінує альтернацію

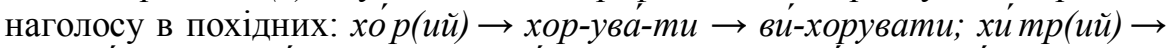
хитр-у' вати $\rightarrow$ ви́ -хитрувати; го́ стр $($ ий $\rightarrow$ гостр-и-ти $\rightarrow$ ви́-гострити.

Консонантні зміни приголосних $\boldsymbol{\kappa} / \mathbf{u}, \boldsymbol{x} / \mathbf{u}, \boldsymbol{z} / / \boldsymbol{s}$ та $\boldsymbol{\kappa} / \boldsymbol{u}^{\prime}, \boldsymbol{u}^{\prime} / / \boldsymbol{u} \mathrm{y}$ застосовані під час творення іменникових дериватів: сі́p (ий) $\rightarrow$ cip'-á $\rightarrow$

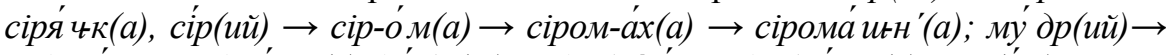

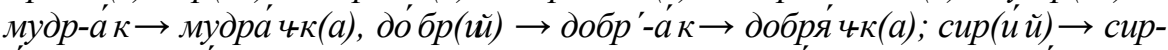
$u^{\prime} u^{\prime}(a) \rightarrow$ cupиччник 'фахівець із вичинення сириці' чо' рн(uй) $\rightarrow$ чорн-й $u^{\prime}(a) \rightarrow$ чорниччк(а), чорни́чник.

Палаталізація (перехідна й неперехідна) кінцевого приголосного основи, що супроводжується чергуванням наголосу, властива багатьом

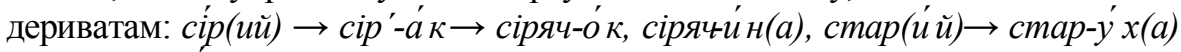
$\rightarrow$ cтаруи-е ниї (a).

Морфонологічну адаптацію компонентів словотвірної структури віддієслівних іменників із значенням опредметненої дії на -iн't'уможливлює усічення дієслівної фіналі, альтернація наголосу 3 тематичного голосного суфікса на дериваційний суфікс: чо́ рн(ий) $\rightarrow$ чорн-

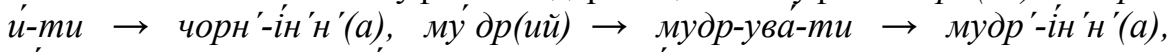

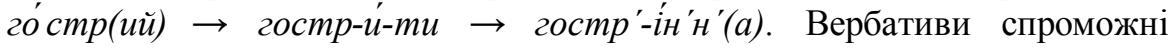
продукувати маскулятиви 3 суфіксами -ун, -'aк, використовуючи комплекс морфонологічних трансформацій - усікання основи й переміщення наголосу, палаталізації $(x u ́ m p(u \check{u}) \rightarrow x u m p-y в a ́-m u \rightarrow x u m p-$

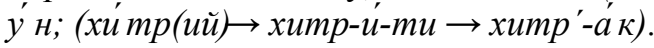

Морфонологічна адаптація твірної основи іменника на -ен' $\boldsymbol{H}^{\prime}-$ зі значенням опредметненої дії відбувається шляхом усікання дієслівної фіналі, переміщення наголосу 3 усіченого тематичного голосного на твірну основу: чо́ рн(ий) $\rightarrow$ чорн-и-ти $\rightarrow$ об-чорни́ ти $\rightarrow$ обчо́ рнен'н' $(a)$; до́бр (ий) $\rightarrow$ добр-и́-ти $\rightarrow$ з-добри́ти $\rightarrow$ здо́бр-ен'н'(а), го́ стр (ий) $\rightarrow$ гостр-и-ти $\rightarrow$ за-гостри ти $\rightarrow$ заго́ стр-ен'н'(a).

Отже, словотвірні гнізда 3 вершинами на тверду морфонему $\{p\}$ позначені неоднаковою словотвірною й морфонологічною активністю. Аналіз морфонологічних трансформацій в обстежених СГ допоміг укласти їхні індивідуальні морфонологічні структури. Типова, або узагальнена, морфонологічна будова всіх індивідуальних морфонологічних структур СГ на -p(uй) засвідчує, що морфонологічна ідентичність вершинних слів породжує однорідну сукупність морфонологічних схем, використаних при творенні похідних. Характерна риса типової морфонологічної структури С Г. В. Пристай, Б. Р. Пристай, 2015. 
залучення до творення похідних дериваційних суфіксів переважно 3 вокалічною морфонемою в зачині. Найпродуктивніші трансформації альтернація консонантів за твердістю / м'якістю, переміщення наголосу на суфікс, нарощення суфікса та їх поєднання.

Перспективами подальших досліджень убачаємо встановлення правил перетворення, що відображають морфонологічні модифікації в словотвірних гніздах із вершиною - непохідним прикметником.

\section{Література}

1. Великий тлумачний словник сучасної української мови : 170000 слів / [уклад. і голов. ред. В. Т. Бусел]. - К. : Ірпінь, ВТФ «Перун», 2001. - 1440 с.

2. Горпинич В. О. Сучасна українська літературна мова. Морфеміка. Словотвір. Морфонологія / В. О. Горпинич. - К. : Вища школа, 1999. - 208 с.

3. Нещименко Г. П. Проблематика деривационной морфонологии Г. П. Нещименко // Славянское и балканское языкознание : проблемы морфонологии / [сб. научн. трудов / науч. ред. Т. Попова и др.]. - М. : Наука, 1981. - С. 302-321.

4. Федурко М. Ю. Морфонологія відіменникового словотворення М. Ю. Федурко. - Київ-Дрогобич : Вимір, 2003. - 271 с.

Стаття надійшла до редакиії 10.08.2015 p. 